\title{
Recent advances in roles of G-protein coupled receptors in intestinal intraepithelial lymphocytes
}

\author{
Hayakazu SUMIDA ${ }^{1}$ \\ ${ }^{1}$ Department of Dermatology, Faculty of Medicine, The University of Tokyo, 7-3-1 Hongo, Bunkyo-ku, Tokyo 113-8655, Japan
}

Received December 23, 2019; Accepted February 23, 2020; Published online in J-STAGE March 6, 2020

\begin{abstract}
Intestinal intraepithelial lymphocytes (IELs) potentially provide the first line of immune defense against enteric pathogens. In addition, there is growing evidence supporting the involvement of IELs in the pathogenesis of gut disorders such as inflammatory bowel diseases. Various kinds of molecules are involved in the dynamics of IELs, such as homing to the intestinal epithelium and retention in the intestinal mucosa. G protein-coupled receptors (GPCRs) comprise the largest family of cell surface receptors and regulate many biological responses. Although some GPCRs, like CCR9, have been implicated to have roles in IEL homing, little is still known regarding the functional roles of GPCRs in IEL biology. In this review, we provide a concise overview of recent advances in the roles of novel GPCRs like GPR55 and GPR18 in the dynamics of IELs.
\end{abstract}

Key words: intestinal intraepithelial lymphocytes, dynamics, G-protein coupled receptors, gut immunology

\section{INTRODUCTION}

Intestinal intraepithelial lymphocytes (IELs) are a heterogeneous $\mathrm{T}$ cell population localized within the intestinal epithelial layer, where they carry out various effector, regulatory, and protective functions [1]. IELs are distributed in the small intestine and large intestine, and it has been estimated that there is one IEL for every 4 to 10 intestinal epithelial cells (IECs) seen in the small intestine and for every 30 to 50 IECs found in the large intestine $[2,3]$. These intraepithelial lymphocytes have been complicated by the heterogeneity of their functions, and these are represented by conventional (induced) and nonconventional (natural) T-cell subsets. On the basis of recent information, it is assumed that IELs play key roles in the induction and regulation of mucosal immunity. Therefore, revealing the mechanisms of the dynamics of IELs should be useful for providing novel therapeutic strategies for inflammatory bowel diseases and for understanding the gut mucosal immune system.

The G protein-coupled receptors (GPCRs) represent the largest and most versatile family of cell surface communicating molecules and are currently the most common targets in the pharmaceutical industry. GPCRs can be activated by a diverse array of ligands, including chemokines and lipid mediators. Therefore, GPCRs are involved in various key pathological and/or physiological processes. A variety of GPCRs and their mediators have been found to be involved in the immune system. Regarding gut immunology, the $\mathrm{C}-\mathrm{C}$ chemokine receptor type 9 (CCR9), also known as CD119, is a member of the GPCR supergene family selectively and functionally expressed on human and murine small-intestinal lymphocytes [4]. Murine data suggest that interactions between CCR9 and its ligand, CCL25, specifically contribute to IEL homing to the small intestine. However, given that CCR9- or CCL25-deficient mice showed decreased numbers of IELs in the small intestine [5], it has been assumed that other GPCRs besides CCR9 must be involved in the dynamics of IELs. Moreover, T-cell homing to the large intestine does not require CCR9, which is not expressed on colonic IELs. In this review, we focus on recent advances in IELs and related GPCRs such as CXCR3, GPR18, GPR55, and GPR15, especially on their dynamics and roles in physiological and/or pathological conditions.

\section{HETEROGENEOUS POPULATION OF IELS}

IELs are a heterogeneous population of T lymphocytes in the human and murine intestine and include both $\mathrm{TCR} \alpha \beta^{+}$and $\mathrm{TCR} \gamma \delta^{+}$IELs. These subsets are further subdivided on the basis of CD8 coreceptor expression. In the small intestine, the overwhelming majority of TCR $\gamma \delta^{+}$IELs are predominantly $\mathrm{V} \gamma 7^{+}$ IELs and express the CD $8 \alpha \alpha$ homodimer in mice, whereas about $10 \%$ of the small intestinal IELs express TCR $\gamma \delta$ in humans [6]. On the other hand, in the colon, the majority of CD8+ cells bear $\mathrm{TCR} \alpha \beta$ and express the $\operatorname{CD} 8 \alpha \beta$ heterodimer $[3,7]$. TCR $\gamma \delta^{+}$ IELs are very different from TCR $\gamma \delta^{+} \mathrm{T}$ cells located in lymphoid tissues, which predominantly lack CD8 expression. Unlike T cell populations in other tissues, most TCR $\alpha \beta^{+}$IELs in the small 
intestine belong to the $\mathrm{CD}^{+}$subset [8]. Moreover, a sizeable fraction of TCR $\alpha \beta^{+}$IELs are $\mathrm{CD} 8 \alpha^{+} \mathrm{CD} 8 \beta^{-}$cells [9], which are referred to as CD8 $\alpha \alpha$ IELs based on their expression of the CD8 $\alpha \alpha$ homodimer. In brief, TCR $\alpha \beta^{+}$IELs in the small intestine mainly consist of CD8 $\alpha \alpha, \mathrm{CD} 8 \alpha \beta$, and CD4. CD $8 \alpha \alpha^{+}$IELs that express TCR $\gamma \delta$ or $\mathrm{TCR} \alpha \beta$ but do not express either CD4 or CD $8 \alpha \beta$ are so-called natural IELs [1]. Regarding surface markers, unconventional CD $8 \alpha \alpha^{+}$IELs do not express molecules typically expressed by conventional $\mathrm{T}$ cells but instead express natural killer cell receptors such as NK1.1 [1]. Moreover, CD8 $\alpha \alpha^{+}$IELs constitutively express tissue-resident markers CD69 and CD103 [10].

\section{IELS AND INTESTINAL PATHOGENS}

The intestine contains a dynamic community of trillions of pathogens. The intestinal immune system has a crucial role in limiting tissue invasion by the resident microbiota and is fundamentally important for preserving the symbiotic nature of these interactions [11]. For these roles, the intestinal immune system must avoid potentially harmful overreactions that could unnecessarily damage intestinal tissues or alter the crucial metabolic functions of the microbiota $[12,13]$. Regarding the contribution of IELs to the system, these cells play a major role in protection against invasion and systemic dissemination of enteric pathogens and commensal bacteria [14, 15]. Although the microbiota has an effect on the composition and number of TCR $\alpha \beta$ IELs, TCR $\gamma \delta$ IEL numbers are unaffected in germ-free mice, indicating that the intestinal microbiota has little to no effect on maintaining TCR $\gamma \delta$ IEL homeostatic numbers [16]. However, intestinal TCR $\gamma \delta$ IELs have high expression of several cytolytic genes, such as granzymes A and B, indicating a cytotoxic potential towards pathogens and infected cells [17, 18]. Thus, TCR $\gamma \delta$ IELs provide early protection of intestinal tissue against resident bacteria $[19,20]$. Furthermore, $\gamma \delta$ TCR-deficient mice, but not $\alpha \beta$ TCR-deficient mice, are more susceptible to infection than control WT mice $[17,19,21]$. In particular, IELs play key roles in the host defense against intestinal pathogens such as Salmonella typhimurium and Toxoplasma gondii [22]. Thus, revealing the mechanisms of the dynamics of IELs should be useful for understanding how IELs contribute to early protection against pathogen entry from the intestinal surface.

\section{DEVELOPMENT AND MATURAION OF IELS}

IELs seem to have a unique development pathway, although controversy remains as to the extent to which IELs are thymus dependent. Conventional IELs, i.e., those originating from circulating $\mathrm{T}$ cells, are activated in lymphoid organs and imprinted for gut homing using $\alpha 4 \beta 7$ and CCR9. On the other hand, unconventional IELs derive from $\mathrm{CD} 8 \alpha \beta$ thymocytes that migrate to the intestinal epithelium and undergo further differentiation into IELs, although some of these IELs may also arise extrathymically $[23,24]$. Of note, naive CD $8 \alpha \beta$ recent thymic emigrants already express $\alpha 4 \beta 7$ and CCR 9 when they leave the thymus, and they directly home to the small intestines in a CCR9- and $\alpha 4 \beta 7$-dependent fashion [25].

The molecular mechanisms regulating gut homing receptor expression on primed T cells in Peyer's patches (PPs) and/ or mesenteric lymph nodes (mLNs) still remain to be fully understood. However, one of the key inducers of gut homing receptors seems to be retinoic acid (RA), a vitamin A (retinol) metabolite [26]. Migratory intestinal DCs in the mLNs or PPs have an ability to process vitamin A to RA for presentation. RA imprints small-intestine homing properties on $\mathrm{T}$ cells activated in the mLNs, by inducing expression of integrin $\alpha 4 \beta 7$ and CCR9 [27-29]. In in vitro experiments, addition of RA to anti-CD3 and anti-CD28 antibodies can induce expression of $\alpha 4 \beta 7$, CCR9, and GPR55 on stimulated $T$ cells in a dose-dependent manner [26, 30].

\section{GPCRS INVOLVED IN IEL HOMING TO AND RETENTION IN THE INTESTINE}

IEL homing to the intestine and retention in the intestinal mucosa are critically dependent on the expression of a variety of gut-specific homing molecules [31]. As for GPCRs, it is well known that T-cell homing to the small intestine requires CCR9 under homeostatic conditions [32]. However, during the inflammatory process, cell recruitment seems to be preferentially guided by other GPCRs, such as CXCR3, which has been suggested to be one of the most relevant chemokine axes that promotes the arrival of cells into inflamed gut tissues [33]. Recently, GPR18 and GPR55 have been reported to be other GPCRs that positively and negatively regulate $\mathrm{CD} 8 \alpha \alpha^{+} \mathrm{TCR} \gamma \delta^{+}$ IEL accumulation in the small intestine, respectively $[30,34]$. These findings on the unique division of reverse roles by GPCRs suggest a complicated and elaborate mechanism underlying IEL homing to the small intestine. In addition, as for colonic IELs, GPR15 controls the specific homing of $\mathrm{T}$ cells to the large intestine $[35,36]$.

\section{CCR9}

The CCR9-CCL25 axis in mice plays a key role in the homing of $\mathrm{CD}^{+} \mathrm{T}$ lymphocytes to the small intestine [29], which is supported by studies using CCR9- or CCL25-deficient mice [5]. On the other hand, the situation in the large intestine is different, as colonic IELs require either $\alpha 4 \beta 7$ or $\alpha 4 \beta 1$, but not CCR9 [37]. In agreement with this, CCL25 was found at a higher concentration in the small intestine but not in the colon within the murine and human small intestine [38-40]. Remarkably, CCL25 expression decreases from the proximal to the distal small intestine in mice [41], and this is consistent with the abundance of IELs in the proximal part compared with the distal part in the small intestine. Of note, CCR9 is also highly expressed on IgA antibody-secreting plasma cells in the $\mathrm{mLN}$ and PP. Given this, CCL25 might selectively attract and direct these cells to the small intestine, where CCR9 is downregulated upon arrival [42-44]. Whether IELs recirculate or not is subject to debate. However, given that human IELs express CCR9 [4], peripheral blood $\mathrm{CCR}^{+} \mathrm{T}$ cells may include recirculating IELs.

\section{CXCR3}

As mentioned above, CCR9 is involved in the migration of IELs into the intestinal mucosa under homeostatic conditions. In addition to this, other GPCRs have been implicated to be involved in IEL recruitment to the small intestinal epithelium. For example, CXCR3 (GPR9/CD183), an interferon-inducible 
chemokine receptor, is expressed on the surface of activated $\mathrm{CD} 8^{+}$IELs, and this CXCR3 expression by gut IELs has been attributed to chronic activation of these cells by pathogens in the lumen. CXCR3 knockout (KO) mice showed a decreased number of CD8 $\alpha \beta^{+}$IELs and increased number of CD $8 \alpha \alpha^{+}$IELs [45]. It is assumed that IEL recruitment is preferentially guided by CXCR3 and its ligands, such as CXCL10, especially in inflamed gut tissues [33, 46-48]. In humans, the CXCR3/CXCL10 signaling axis is overactivated in the small intestinal mucosa in untreated celiac disease patients with increased production of CXCL10 in the epithelium primarily by enterocytes [49]. This axis is known to be active not only in inflammatory bowel diseases but also in different chronic inflammatory processes [50]. Given the significance of CXCR3 in the inflamed condition rather than the homeostatic condition, this GPCR might be an ideal target for the treatment of inflammatory bowel diseases.

\section{GPR18}

Recently, several novel GPCRs have been reported to play roles in the $\mathrm{T}$ cell homing to the small intestine. The orphan receptor, G protein-coupled receptor 18 (GPR18), has been considered to be a putative cannabinoid receptor. Considering the high expression of GPR18 in immune cells, including CD8+ T cells, GPR18 is proposed and reported to have an immunological function, especially in CD8 T cells [51]. GPR18 is abundantly expressed in CD8 $\alpha \alpha^{+}$IELs in the murine small intestine. GPR18 $\mathrm{KO}$ mice showed reduced numbers of CD $8 \alpha \alpha^{+} \mathrm{TCR} \gamma \delta^{+}$IELs [34, 51,52], showing that GPR18 and CCR9 have roles in augmenting the accumulation of CD8 $\mathrm{T}$ cells in the intestinal intraepithelial lymphocyte compartment compared with the lamina propria compartment. In detail, the GPR18-deficient TCR $\gamma \delta^{+}$IELs that remained had elevated Thy1, and there were fewer granzyme $\mathrm{B}^{+}$ and $\mathrm{V} \gamma 7^{+}$cells, indicating a greater reduction in effector-type cells [34]. Therefore, GPR18 is possibly involved in IEL maturation.

\section{GPR55}

GPR55 was originally identified as an atypical cannabinoid receptor, and lysophosphatidylinositol (LPI) was subsequently found to be an endogenous ligand for GPR55 [53]. GPR55 has been reported to be involved in various physiological and pathological processes, such as in the central nervous system or bone dynamics $[54,55]$. Recently, GPR55 was revealed to mediate migration inhibition in response to LPl. LPI inhibited IEL migration to the CCR9 ligand, CCL25, and this effect was lost when using IELs from GRP55-deficient mice. The inhibitory effect of LPI was most potent for $\gamma \delta$ T IELs, which showed remarkably high endogenous expression of GPR55 [30]. In mice lacking GPR55, there was a selective increase in $\gamma \delta \mathrm{T}$ IEL cell frequencies and numbers. To support this, multiple forms of LPI were detected in the small intestine by LC-MS/MS. These lines of observation showed that GPR55 negatively regulates $\mathrm{CD} 8 \alpha \alpha^{+} \mathrm{TCR} \gamma \delta^{+}$IEL accumulation in the small intestine [30]. Notably, GPR55 is the first reported molecule that can inhibit IEL homing to the small intestine. IELs are distributed throughout the epithelium in the small intestine. Even under homeostatic conditions, IELs actively migrate almost exclusively in the space between the epithelial layer and the basement membrane and showed transient movements in close association with epithelial cells $[30,56,57]$. Although some molecules, such as transforming growth factor (TGF)- $\beta$, are reported to be crucial for IEL retention in the epithelium [58], which GPCRs are involved in IEL retention in the intestinal mucosa has remained obscure. Intravital imaging showed that GPR55-deficient IELs migrate faster and interact more extensively with epithelial cells. From a pathological perspective, GPR55 deficiency in $\gamma \delta \mathrm{T}$ IELs protects mice from indomethacin-induced intestinal damage, possibly due to the frequent IEL-epithelial cell crosstalk [30].

\section{GPR15}

Compared with IELs in the small intestine, a lot still remains unknown about the factors controlling the dynamics of colonic IELs. The epithelium of the large intestine produces the chemokine CCL28, which binds to the receptor CCR10. Although CCR10 mediates localization of plasmablasts to the colon, CCR10 is not expressed on colonic IELs and does not appear to contribute to their recruitment [59]. However, GPR15 was recently revealed to mediate homing of regulatory $\mathrm{T}$ (Treg) cells in the mucosa of the large intestine [35]. In addition, GPR15 is also expressed by mouse Th17 and Th1 effector cells [36]. GPR15-mediated Treg homing is required for efficient control of gut inflammation in a Citrobacter rodentium-induced colitis model [35]. Moreover, GPR15-mediated T-effector-cell homing is crucial in the pathogenesis in the T-cell transfer colitis model [36]. In humans, it is noteworthy that GPR 15 is expressed by effector cells, including pathogenic Th2 cells, in ulcerative colitis but is not expressed by Treg cells [36]. Thus, GPR15 may help target pathogenic Th2 cells to the colon in humans but is probably less important in humans than in the mouse for the homing and function of Treg cells in the gut wall. Future studies of the role of this chemoattractant receptor in intestinal immune biology are required, and identification of the physiologic ligand(s) for GPR15 might help us understand the dynamics of colonic IELs.

\section{CONCLUSION}

As described in this review, gut IELs are a heterogeneous population, and several GPCRs have unique roles in the dynamics of IELs (Fig. 1). Future studies should be performed to define the detailed mechanisms of IEL homing to and retention in the gut epithelium under physiological and pathological conditions. IELs and their interaction with epithelial cells are crucial for intestinal homeostasis, immune surveillance, and maintenance in epithelial integrity [60]. These crucial roles contribute to tissue damage and inflammatory bowel diseases [61, 62] and celiac disease [63, 64]. In addition, IELs contribute to host-microbial relationships. Specifically, intestinal bacteria are linked to the number of IELs and their activation $[19,65,66]$. Several studies suggest that intestinal IELs play roles in limiting mucosal penetration by intestinal pathogens during tissue homeostasis and/or following epithelial damage $[19,21,22,67]$. As described in this review, although a lot remains unclear, recent accumulating evidence has revealed that novel GPCRs regulate the dynamics of IELs in a unique manner. Recent technological advances will help us to find more novel GPCRs and make further advances in understanding the functions of IELs in the near future. Furthermore, given that GPCRs represent the leading family of validated drug targets in biomedicine, insights concerning the involvement of functional 


\section{Small intestine}

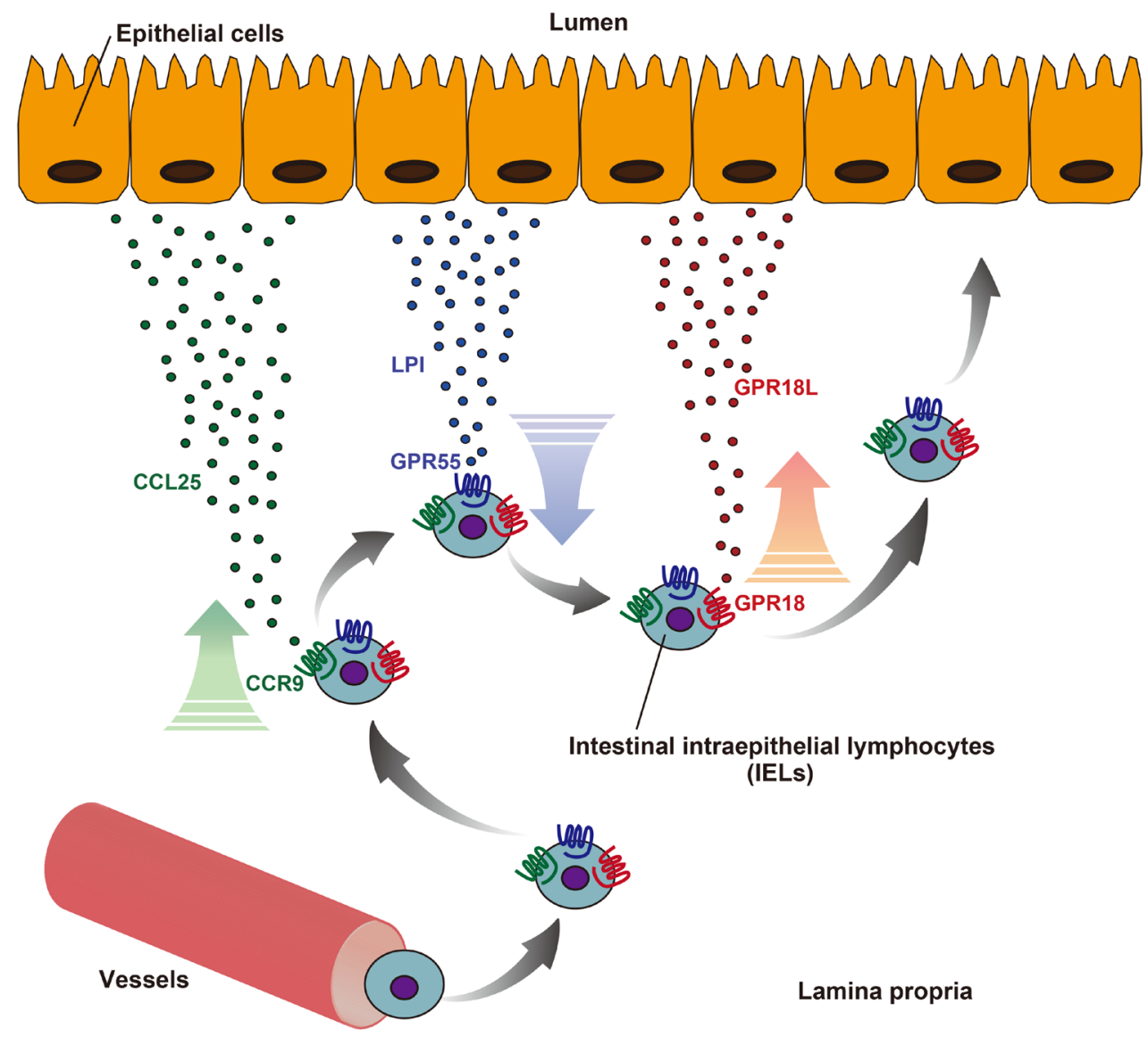

Fig. 1. Dynamics of intestinal intraepithelial lymphocytes (IELs) regulated by G-protein coupled receptors (GPCRs) in the small intestine. A variety of GPCRs are involved in the IEL homing to the intestinal epithelium. CCR9 and GPR18 have roles in augmenting the accumulation of CD8 T cells in the intestinal intraepithelial lymphocyte compartment. On the other hand, GPR55, a receptor that mediates migration inhibition in response to lysophosphatidylinositol (LPI), negatively regulates $\mathrm{CD} 8 \alpha \alpha^{+} \mathrm{TCR} \gamma \delta^{+}$IEL accumulation in the epithelium. GPR $18 \mathrm{~L}$, ligands for GPR 18 .

GPCRs in the dynamics of IELs may provide new therapeutic strategies for various intestinal diseases, including inflammatory bowel disease and viral/bacterial infections.

\section{CONFLICT OF INTEREST}

None.

\section{REFERENCES}

1. Cheroutre H, Lambolez F, Mucida D. 2011. The light and dark sides of intestinal intraepithelial lymphocytes. Nat Rev Immunol 11: 445-456. [Medline] [CrossRef]

2. Cheroutre H. 2004. Starting at the beginning: new perspectives on the biology of mucosal T cells. Annu Rev Immunol 22: 217-246. [Medline] [CrossRef]

3. Beagley KW, Fujihashi K, Lagoo AS, Lagoo-Deenadaylan S, Black CA, Murray AM, Sharmanov AT, Yamamoto M, McGhee JR, Elson CO, et al. 1995. Differences in intraepithelial lymphocyte $\mathrm{T}$ cell subsets isolated from murine small versus large intestine. J Immunol 154: 5611-5619. [Medline]

4. Zabel BA, Agace WW, Campbell JJ, Heath HM, Parent D, Roberts AI, Ebert EC, Kassam N, Qin S, Zovko M, LaRosa GJ, Yang LL, Soler D, Butcher EC, Ponath PD, Parker CM, Andrew DP. 1999. Human G protein-coupled receptor GPR-9-6/CC chemokine receptor 9 is selectively expressed on intestinal homing $\mathrm{T}$ lymphocytes, mucosal lymphocytes, and thymocytes and is required for thymus-expressed chemokine-mediated chemotaxis. J Exp Med 190: 1241-1256. [Medline] [CrossRef]

5. Wurbel MA, Malissen M, Guy-Grand D, Malissen B, Campbell JJ. 2007. Impaired accumulation of antigen-specific CD8 lymphocytes in chemokine CCL25-deficient intestinal epithelium and lamina propria. J Immunol 178: 7598-7606. [Medline] [CrossRef]

6. McDonald BD, Jabri B, Bendelac A. 2018. Diverse developmental pathways of intestinal intraepithelial lymphocytes. Nat Rev Immunol 18: 514-525. [Medline] [CrossRef]

7. Boll G, Rudolphi A, Spiess S, Reimann J. 1995. Regional specialization of intraepithelial T cells in the murine small and large intestine. Scand J Immunol 41: 103-113. [Medline] [CrossRef]

8. Camerini V, Panwala C, Kronenberg M. 1993. Regional specialization of the mucosal immune system. Intraepithelial lymphocytes of the large intestine have a different phenotype and function than those of the small intestine. J Immunol 151: 1765-1776. [Medline]

9. Sheridan BS, Lefrançois L. 2010. Intraepithelial lymphocytes: to serve and protect. Curr Gastroenterol Rep 12: 513-521. [Medline] [CrossRef]

10. Wang HC, Zhou Q, Dragoo J, Klein JR. 2002. Most murine CD8+ intestinal intraepithelial lymphocytes are partially but not fully activated T cells. J Immunol 169: 4717-4722. [Medline] [CrossRef]

11. Nielsen MM, Witherden DA, Havran WL. 2017. $\gamma \delta \mathrm{T}$ cells in homeostasis and host defence of epithelial barrier tissues. Nat Rev Immunol 17: 733-745. [Medline] [CrossRef]

12. Hooper LV, Macpherson AJ. 2010. Immune adaptations that maintain homeostasis with the intestinal microbiota. Nat Rev Immunol 10: 159-169. [Medline] [CrossRef]

13. Salzman NH, Ghosh D, Huttner KM, Paterson Y, Bevins CL. 2003. Protection against enteric salmonellosis in transgenic mice expressing a human intestinal defensin. Nature 422: 522-526. [Medline] [CrossRef]

14. Kunisawa J, Takahashi I, Kiyono H. 2007. Intraepithelial lymphocytes: their shared and divergent immunological behaviors in the small and large intestine. Immunol Rev 215: 136-153. [Medline] [CrossRef] 
15. Cheroutre H. 2005. IELs: enforcing law and order in the court of the intestinal epithelium. Immunol Rev 206: 114-131. [Medline] [CrossRef]

16. Bandeira A, Mota-Santos T, Itohara S, Degermann S, Heusser C, Tonegawa S, Coutinho A. 1990. Localization of gamma/delta T cells to the intestinal epithelium is independent of normal microbial colonization. J Exp Med 172: 239-244. [Medline] [CrossRef]

17. Fahrer AM, Konigshofer Y, Kerr EM, Ghandour G, Mack DH, Davis MM, Chien YH. 2001. Attributes of gammadelta intraepithelial lymphocytes as suggested by their transcriptional profile. Proc Natl Acad Sci USA 98: 10261-10266. [Medline] [CrossRef]

18. Shires J, Theodoridis E, Hayday AC. 2001. Biological insights into TCRgammadelta+ and TCRalphabeta+ intraepithelial lymphocytes provided by serial analysis of gene expression (SAGE). Immunity 15: 419-434. [Medline] [CrossRef]

19. Ismail AS, Severson KM, Vaishnava S, Behrendt CL, Yu X, Benjamin JL, Ruhn KA, Hou B, DeFranco AL, Yarovinsky F, Hooper LV. 2011. Gammadelta intraepithelial lymphocytes are essential mediators of host-microbial homeostasis at the intestinal mucosal surface. Proc Natl Acad Sci USA 108: 8743-8748. [Medline] [CrossRef]

20. Ismail AS, Behrendt CL, Hooper LV. 2009. Reciprocal interactions between commensal bacteria and gamma delta intraepithelial lymphocytes during mucosal injury. J Immunol 182: 3047-3054. [Medline] [CrossRef]

21. Dalton JE, Cruickshank SM, Egan CE, Mears R, Newton DJ, Andrew EM, Lawrence B, Howell G, Else KJ, Gubbels MJ, Striepen B, Smith JE, White SJ, Carding SR. 2006. Intraepithelial gammadelta+ lymphocytes maintain the integrity of intestinal epithelial tight junctions in response to infection. Gastroenterology 131: 818-829. [Medline] [CrossRef]

22. Edelblum KL, Singh G, Odenwald MA, Lingaraju A, El Bissati K, McLeod R, Sperling AI, Turner JR. 2015. $\gamma \delta$ intraepithelial lymphocyte migration limits transepithelial pathogen invasion and systemic disease in mice. Gastroenterology 148: 1417-1426. [Medline] [CrossRef]

23. Poussier P, Edouard P, Lee C, Binnie M, Julius M. 1992. Thymus-independent development and negative selection of $\mathrm{T}$ cells expressing $\mathrm{T}$ cell receptor alpha/beta in the intestinal epithelium: evidence for distinct circulation patterns of gut- and thymusderived T lymphocytes. J Exp Med 176: 187-199. [Medline] [CrossRef]

24. Mosley RL, Styre D, Klein JR. 1990. Differentiation and functional maturation of bone marrow-derived intestinal epithelial $\mathrm{T}$ cells expressing membrane $\mathrm{T}$ cell receptor in athymic radiation chimeras. J Immunol 145: 1369-1375. [Medline]

25. Staton TL, Habtezion A, Winslow MM, Sato T, Love PE, Butcher EC. 2006. CD8+ recent thymic emigrants home to and efficiently repopulate the small intestine epithelium. Nat Immunol 7: 482-488. [Medline] [CrossRef]

26. Iwata M, Hirakiyama A, Eshima Y, Kagechika H, Kato C, Song SY. 2004. Retinoic acid imprints gut-homing specificity on T cells. Immunity 21: 527-538. [Medline] [CrossRef]

27. Mora JR, Bono MR, Manjunath N, Weninger W, Cavanagh LL, Rosemblatt M, Von Andrian UH. 2003. Selective imprinting of gut-homing T cells by Peyer's patch dendritic cells. Nature 424: 88-93. [Medline] [CrossRef]

28. Stagg AJ, Kamm MA, Knight SC. 2002. Intestinal dendritic cells increase T cell expression of alpha4beta7 integrin. Eur J Immunol 32: 1445-1454. [Medline] [CrossRef]

29. Johansson-Lindbom B, Svensson M, Wurbel MA, Malissen B, Márquez G, Agace W. 2003. Selective generation of gut tropic T cells in gut-associated lymphoid tissue (GALT): requirement for GALT dendritic cells and adjuvant. J Exp Med 198: 963-969. [Medline] [CrossRef]

30. Sumida H, Lu E, Chen H, Yang Q, Mackie K, Cyster JG. 2017. GPR55 regulates intraepithelial lymphocyte migration dynamics and susceptibility to intestinal damage. Sci Immunol 2: eaao1135. [Medline] [CrossRef]

31. Sumida H. 2019. Dynamics and clinical significance of intestinal intraepithelial lymphocytes. Immunol Med 42: 117-123. [Medline] [CrossRef]

32. Wurbel MA, Malissen M, Guy-Grand D, Meffre E, Nussenzweig MC, Richelme M, Carrier A, Malissen B. 2001. Mice lacking the CCR9 CC-chemokine receptor show a mild impairment of early T- and B-cell development and a reduction in T-cell receptor gammadelta $(+)$ gut intraepithelial lymphocytes. Blood 98: 2626-2632. [Medline] [CrossRef]

33. Groom JR, Luster AD. 2011. CXCR3 in T cell function. Exp Cell Res 317: 620-631. [Medline] [CrossRef]

34. Wang X, Sumida H, Cyster JG. 2014. GPR18 is required for a normal CD8 $\alpha \alpha$ intestinal intraepithelial lymphocyte compartment. J Exp Med 211: 2351-2359. [Medline] [CrossRef]

35. Kim SV, Xiang WV, Kwak C, Yang Y, Lin XW, Ota M, Sarpel U, Rifkin DB, Xu R, Littman DR. 2013. GPR15-mediated homing controls immune homeostasis in the large intestine mucosa. Science 340: 1456-1459. [Medline] [CrossRef]

36. Nguyen LP, Pan J, Dinh TT, Hadeiba H, O'Hara E 3rd, Ebtikar A, Hertweck A, Gökmen MR, Lord GM, Jenner RG, Butcher EC, Habtezion A. 2015. Role and speciesspecific expression of colon T cell homing receptor GPR15 in colitis. Nat Immunol 16: 207-213. [Medline] [CrossRef]

37. Mora JR, von Andrian UH. 2006. T-cell homing specificity and plasticity: new concepts and future challenges. Trends Immunol 27: 235-243. [Medline] [CrossRef]

38. Koenecke C, Förster R. 2009. CCR9 and inflammatory bowel disease. Expert Opin
Ther Targets 13: 297-306. [Medline] [CrossRef]

39. Kunkel EJ, Campbell JJ, Haraldsen G, Pan J, Boisvert J, Roberts AI, Ebert EC, Vierra MA, Goodman SB, Genovese MC, Wardlaw AJ, Greenberg HB, Parker CM, Butcher EC, Andrew DP, Agace WW. 2000. Lymphocyte CC chemokine receptor 9 and epithelial thymus-expressed chemokine (TECK) expression distinguish the small intestinal immune compartment: epithelial expression of tissue-specific chemokines as an organizing principle in regional immunity. J Exp Med 192: 761-768. [Medline] [CrossRef]

40. Papadakis KA, Prehn J, Nelson V, Cheng L, Binder SW, Ponath PD, Andrew DP, Targan SR. 2000. The role of thymus-expressed chemokine and its receptor CCR9 on lymphocytes in the regional specialization of the mucosal immune system. J Immunol 165: 5069-5076. [Medline] [CrossRef]

41. Stenstad H, Svensson M, Cucak H, Kotarsky K, Agace WW. 2007. Differential homing mechanisms regulate regionalized effector $\mathrm{CD} 8$ alphabeta $+\mathrm{T}$ cell accumulation within the small intestine. Proc Natl Acad Sci USA 104: 10122-10127. [Medline] [CrossRef]

42. Bowman EP, Kuklin NA, Youngman KR, Lazarus NH, Kunkel EJ, Pan J, Greenberg HB, Butcher EC. 2002. The intestinal chemokine thymus-expressed chemokine (CCL25) attracts IgA antibody-secreting cells. J Exp Med 195: 269-275. [Medline] [CrossRef]

43. Pabst O, Ohl L, Wendland M, Wurbel MA, Kremmer E, Malissen B, Förster R. 2004 Chemokine receptor CCR9 contributes to the localization of plasma cells to the small intestine. J Exp Med 199: 411-416. [Medline] [CrossRef]

44. Hieshima K, Kawasaki Y, Hanamoto H, Nakayama T, Nagakubo D, Kanamaru A, Yoshie O. 2004. CC chemokine ligands 25 and 28 play essential roles in intestinal extravasation of IgA antibody-secreting cells. J Immunol 173: 3668-3675. [Medline] [CrossRef]

45. Annunziato F, Cosmi L, Liotta F, Lazzeri E, Romagnani P, Angeli R, Lasagni L, Manetti R, Marra F, Gerard C, Petrai I, Dello Sbarba P, Tonelli F, Maggi E, Romagnani S. 2006. CXCR3 and alphaEbeta7 integrin identify a subset of CD8+ mature thymocytes that share phenotypic and functional properties with CD8+ gut intraepithelial lymphocytes. Gut 55: 961-968. [Medline] [CrossRef]

46. Schroepf S, Kappler R, Brand S, Prell C, Lohse P, Glas J, Hoster E, Helmbrecht J, Ballauff A, Berger M, von Schweinitz D, Koletzko S, Lacher M. 2010. Strong overexpression of CXCR3 axis components in childhood inflammatory bowel disease. Inflamm Bowel Dis 16: 1882-1890. [Medline] [CrossRef]

47. Hosomi S, Oshitani N, Kamata N, Sogawa M, Okazaki H, Tanigawa T, Yamagami H, Watanabe K, Tominaga K, Watanabe T, Fujiwara Y, Maeda K, Hirakawa K, Arakawa T. 2011. Increased numbers of immature plasma cells in peripheral blood specifically overexpress chemokine receptor CXCR3 and CXCR4 in patients with ulcerative colitis. Clin Exp Immunol 163: 215-224. [Medline] [CrossRef]

48. Østvik AE, Granlund AV, Bugge M, Nilsen NJ, Torp SH, Waldum HL, Damås JK, Espevik T, Sandvik AK. 2013. Enhanced expression of CXCL10 in inflammatory bowel disease: potential role of mucosal Toll-like receptor 3 stimulation. Inflamm Bowel Dis 19: 265-274. [Medline] [CrossRef]

49. Bondar C, Araya RE, Guzman L, Rua EC, Chopita N, Chirdo FG. 2014. Role of CXCR3/CXCL10 axis in immune cell recruitment into the small intestine in celiac disease. PLoS One 9: e89068. [Medline] [CrossRef]

50. Laragione T, Brenner M, Sherry B, Gulko PS. 2011. CXCL10 and its receptor CXCR3 regulate synovial fibroblast invasion in rheumatoid arthritis. Arthritis Rheum 63: 3274-3283. [Medline] [CrossRef]

51. Sumida H, Cyster JG. 2018. G-protein coupled receptor 18 contributes to establishment of the CD8 effector T cell compartment. Front Immunol 9: 660. [Medline] [CrossRef]

52. Becker AM, Callahan DJ, Richner JM, Choi J, DiPersio JF, Diamond MS, Bhattacharya D. 2015. GPR18 controls reconstitution of mouse small intestine intraepithelia lymphocytes following bone marrow transplantation. PLoS One 10: e0133854. [Medline] [CrossRef]

53. Oka S, Nakajima K, Yamashita A, Kishimoto S, Sugiura T. 2007. Identification of GPR55 as a lysophosphatidylinositol receptor. Biochem Biophys Res Commun 362: 928-934. [Medline] [CrossRef]

54. Leo LM, Familusi B, Hoang M, Smith R, Lindenau K, Sporici KT, Brailoiu E, Abood ME, Brailoiu GC. 2019. GPR55-mediated effects on brain microvascular endothelial cells and the blood-brain barrier. Neuroscience 414: 88-98. [Medline] [CrossRef]

55. Whyte LS, Ryberg E, Sims NA, Ridge SA, Mackie K, Greasley PJ, Ross RA, Rogers MJ. 2009. The putative cannabinoid receptor GPR55 affects osteoclast function in vitro and bone mass in vivo. Proc Natl Acad Sci USA 106: 16511-16516. [Medline] [CrossRef]

56. Hoytema van Konijnenburg DP, Reis BS, Pedicord VA, Farache J, Victora GD, Mucida D. 2017. Intestinal epithelial and intraepithelial T cell crosstalk mediates a dynamic response to infection. Cell 171: 783-794.e13. [Medline] [CrossRef]

57. Edelblum KL, Shen L, Weber CR, Marchiando AM, Clay BS, Wang Y, Prinz I, Malissen B, Sperling AI, Turner JR. 2012. Dynamic migration of $\gamma \delta$ intraepithelial lymphocytes requires occludin. Proc Natl Acad Sci USA 109: 7097-7102. [Medline] [CrossRef]

58. Suzuki R, Nakao A, Kanamaru Y, Okumura K, Ogawa H, Ra C. 2002. Localization of intestinal intraepithelial $\mathrm{T}$ lymphocytes involves regulation of alphaEbeta7 expression by transforming growth factor- $\beta$. Int Immunol 14: 339-345. [Medline] [CrossRef]

59. Lazarus NH, Kunkel EJ, Johnston B, Wilson E, Youngman KR, Butcher EC. 2003. 
A common mucosal chemokine (mucosae-associated epithelial chemokine/CCL28) selectively attracts IgA plasmablasts. J Immunol 170: 3799-3805. [Medline] [CrossRef]

60. Chen Y, Chou K, Fuchs E, Havran WL, Boismenu R. 2002. Protection of the intestinal mucosa by intraepithelial gamma delta T cells. Proc Natl Acad Sci USA 99: 1433814343. [Medline] [CrossRef]

61. Yeung MMW, Melgar S, Baranov V, Oberg A, Danielsson A, Hammarström S, Hammarström ML. 2000. Characterisation of mucosal lymphoid aggregates in ulcerative colitis: immune cell phenotype and TcR-gammadelta expression. Gut 47: 215-227. [Medline] [CrossRef]

62. Kanazawa H, Ishiguro Y, Munakata A, Morita T. 2001. Multiple accumulation of Vdelta2+ gammadelta T-cell clonotypes in intestinal mucosa from patients with Crohn's disease. Dig Dis Sci 46: 410-416. [Medline] [CrossRef]

63. Halstensen TS, Scott H, Brandtzaeg P. 1989. Intraepithelial T cells of the TcR gamma/ delta+ CD8- and V delta $1 / \mathrm{J}$ delta $1+$ phenotypes are increased in coeliac disease.
Scand J Immunol 30: 665-672. [Medline] [CrossRef]

64. Mazzarella G, Stefanile R, Camarca A, Giliberti P, Cosentini E, Marano C, Iaquinto G, Giardullo N, Auricchio S, Sette A, Troncone R, Gianfrani C. 2008. Gliadin activates HLA class I-restricted CD8 $+\mathrm{T}$ cells in celiac disease intestinal mucosa and induces the enterocyte apoptosis. Gastroenterology 134: 1017-1027. [Medline] [CrossRef]

65. Jiang W, Wang X, Zeng B, Liu L, Tardivel A, Wei H, Han J, MacDonald HR, Tschopp J, Tian Z, Zhou R. 2013. Recognition of gut microbiota by NOD2 is essential for the homeostasis of intestinal intraepithelial lymphocytes. J Exp Med 210: 2465-2476. [Medline] [CrossRef]

66. Cheng HY, Ning MX, Chen DK, Ma WT. 2019. Interactions between the gut microbiota and the host innate immune response against pathogens. Front Immunol 10: 607. [Medline] [CrossRef]

67. Inagaki-Ohara K, Sakamoto Y, Dohi T, Smith AL. 2011. $\gamma \delta$ T cells play a protective role during infection with Nippostrongylus brasiliensis by promoting goblet cell function in the small intestine. Immunology 134: 448-458. [Medline] [CrossRef] 